\title{
Size-related decrease in spatial refuge use by Iceland scallops Chlamys islandica: ontogenetic behavioural changes or decreasing refuge availability?
}

\author{
David J. Arsenault, John H. Himmelman* \\ Département de Biologie and GIROQ, Université Laval, Québec, QC, Canada G1K 7 P4
}

\begin{abstract}
We examined whether the size-related shift from refuges to exposed surfaces by Iceland scallops Chlamys islandica in the Mingan Islands, northern Gulf of St. Lawrence, eastern Canada, is caused by behavioural changes in their tendency to use refuges or by decreasing refuge availability as they increase in size. A laboratory experiment indicated that the frequency of refuge use did not vary with scallop size, when the entrance to available refuges was sufficiently large, which suggests that the tendency of scallops to use refuges does not change during ontogeny. The size of crevices used increased with scallop size, indicating that the size structure of refuges potentially could determine size-specific refuge use. Our field observations using SCUBA indicated that the availability of suitably sized refuges (shells of the bivalve Spisula polynyma) decreased markedly with increasing scallop size. Size-related changes in the frequency of refuge use were positively correlated with refuge availability, suggesting that the shift from refuges to exposed surfaces is caused by decreasing availability of suitably sized refuges as scallops increase in size. However, the density of refuges was generally greater than the density of scallops, which suggested that refuges were utilized below their carrying capacity. The proportion of adequately sized refuges which were occupied by scallops was low $(<15 \%)$ and decreased with increasing scallop size, possibly because scallops had increasing difficulty in locating refuges of suitable size as they increased in size. That the shells used as refuges by scallops covered only $6.4 \%$ of the bottom should decrease the probability of their being found. Further, because the frequency of suitable refuges decreased with increasing scallop size, scallops should progressively have increasing difficulty in locating refuges. This would likely increase the time scallops are exposed to predators while searching for refuges, which is likely to be critical for small scallops given their high vulnerability to predators. Hence, encounter rates with refuges could potentially produce a demographic bottleneck in respect to survival of recruits.
\end{abstract}

KEY WORDS: Chlamys islandica $\cdot$ Scallop $\cdot$ Habitat $\cdot$ Refuges $\cdot$ Crevices $\cdot$ Size $\cdot$ Scaling

\section{INTRODUCTION}

Predation is a major factor affecting prey populations because of its influence on distribution, abundance and size structure. Its strong selective pressure has favoured the development of a wide variety of adaptations by prey to increase survival, such as defensive morphologies, escape responses and avoidance behav-

- Addressee for correspondence.

E-mail: john.himmelman@bio.ulaval.ca iours (Sih 1987). As vulnerability to predators is generally inversely related to size, juvenile stages often avoid being detected by predators by hiding in refuges, such as dense vegetation (Heck \& Wilson 1987, Main 1987, Werner \& Hall 1988, Pohle et al. 1991) or crevices (Stein \& Magnuson 1976, Steger 1987, Wahle \& Steneck 1992). Survival may also be enhanced by maximizing growth rates so as to reduce the time needed to attain a less vulnerable size (Seed \& Brown 1978, Caldwell et al. 1980, Semlitsch \& Gibbons 1988). Prey often undergo habitat shifts during 
ontogeny. In some cases, the latter involve a trade-off between survival and growth opportunities, as avoiding predators may limit foraging opportunities (Werner 1.988, Rowe \& Ludwig 1991). Alternatively, habitat shifts may arise because of decreasing availability of suitable refuges as body size increases. Animals that increase in size by orders of magnitude must continuously search for larger and larger refuges which are generally of decreasing availability (Caddy \& Stamatopoulos 1990). This may decrease survival by increasing exposure to predators while searching for refuges. In this way, the abundance and sizes of refuges may cause density-dependent regulation of the abundance and size structure of crevice-dwelling animals (Vance 1972a, b, Howard 1980, Steger 1987. Moran \& Reaka 1988).

The Iceland scallop Chlamys islandica (Bivalvia: Pectinidae) is found in cold water regions of the North Atlantic and Arctic Oceans and is generally associated with coarse substrata in areas with strong tidal currents (Ekman 1953, Wiborg 1963, Arsenault \& Himmelman 1996a). C. islandica is one of the largest species of its genus and attains $110 \mathrm{~mm}$ in shell height in the northern Gulf of St. Lawrence, eastern Canada (Giguère \& Miller 1993, Arsenault \& Himmelman 1996a). Small byssate species of Chlamys generally occupy crevices under rocks or other benthic structures whereas larger species live in exposed habitats (Kauffman 1969, Gilkinson \& Gagnon 1991). In the Mingan Islands, northern Gulf of St. Lawrence, C. islandica exhibits both life habits during its ontogeny, being mostly cryptic at small sizes and gradually exploiting exposed surfaces as it increases in size (Arsenault \& Himmelman $1996 \mathrm{a}, \mathrm{b})$. As for other scallops, small C. islandica are particularly vulnerable to predators, especially decapods (Arsenault \& Himmelman 1996a, b). Arsenault \& Himmelman (1996b) showed that juvenile C. islandica in the Mingan Islands decrease their vulnerability to predators by hiding underneath bivalve shells (mostly of Spisula polynyma) and rocks. In contrast to other animals that change habitats during ontogeny (Werner \& Hall 1988, L'Abée-Lund et al. 1993, Olson 1996), the size-related shift from crevices to exposed surfaces by Iceland scallops does not involve a tradeoff between survival and growth, as using refuges enhances both survival (Arsenault \& Himmelman 1996b) and growth (Arsenault et al. 1997)

The present study uses a laboratory experiment and field measurements to examine the following alternative hypotheses to explain the size-related habitat shift by Iceland scallops in the Mingan Islands: (1) that it is caused by size-related behavioural changes in the tendency to use refuges and (2) that it results from decreasing availability of suitable refuges as scallops increase in size.
A

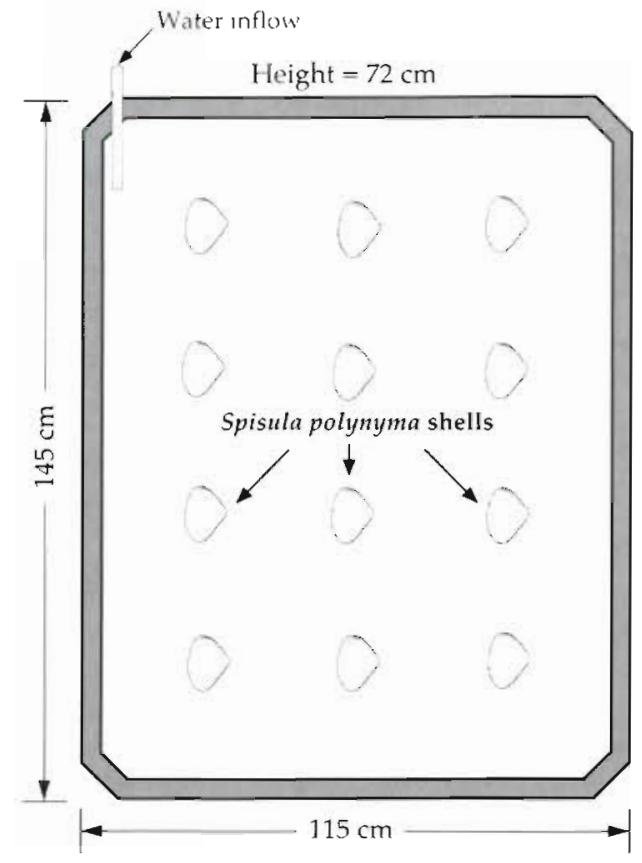

B

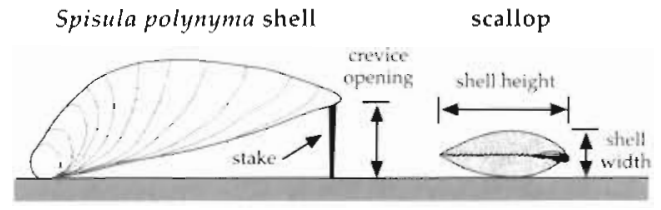

Fig. 1. Schematic representation of the experimental setup used to examine the effect of crevice size on size-specific refuge use by Iceland scallops Chlamys islandica. (A) Top view of the experimental tank showing the arrangement of Spisula polynyma shells used as refuges for scallops. (B) Side view of a $S$. polynyma shell and a scallop showing their respective dimensions

\section{METHODS}

Effect of crevice size on size-specific refuge use. We used a laboratory experiment to examine whether the size-related shift by Iceland scallops from refuges to exposed surfaces results from changes in the tendency to use refuges or from changes in refuge accessibility as scallops increase in size. Scallops of 3 size groups (15-30, 30-45 and 45-60 mm shell height) were collected by SCUBA divers at $15 \mathrm{~m}$ depth at Île du Fantôme, Mingan Islands $\left(50^{\circ} 13^{\prime} 6^{\prime \prime} \mathrm{N}, 63^{\circ} 41^{\prime} 12^{\prime \prime} \mathrm{W}\right)$ and allowed to acclimatize to laboratory conditions in 10001 holding tanks for $24 \mathrm{~h}$ prior to experimentation. We also collected 24 shells of the bivalve Spisula polynyma of similar size (111 to $129 \mathrm{~mm}$ shell length, 80 to $94 \mathrm{~mm}$ shell height) to use as refuges for scallops in our experiment. The shells were brushed thoroughly in freshwater to remove attached fouling organisms and byssal 
threads. We constructed 2 groups of refuges with openings of $15 \mathrm{~mm}(14.8 \pm 0.3 \mathrm{~mm}, \bar{x} \pm \mathrm{SE})$ and $25 \mathrm{~mm}$ $(25.8 \pm 0.4 \mathrm{~mm})$, respectively, using plastic stakes attached to the margin of the shells. Twelve shells with similar crevice openings were placed in a $4 \times 3$ arrangement along the bottom of a $1150 \mathrm{l}$ tank (Fig. 1). The shells occupied $\sim 7 \%$ of the tank's bottom. Fifteen scallops of a given size group were then placed at random positions on the bottom. After $3 \mathrm{~h}$, we recorded the proportion of scallops which were found in refuges. After each trial, we emptied the tank and thoroughly brushed its inside surfaces to remove any byssal threads. To evaluate if visual stimuli were required in locating refuges, we performed trials both in the presence and absence of light from a $60 \mathrm{~W}$ fluorescent lamp suspended $2 \mathrm{~m}$ above the tank. In the trials without illumination an opaque cover was placed over the tank to ensure total darkness. The different treatment combinations (scallop size, crevice size and light) were replicated 3 times and were performed in a random order. Each scallop was used in only 1 trial. The same $S$. polynyma shells were used in all trials, but were thoroughly cleaned and placed at randomly selected positions before each trial. The tank was continuously supplied with water (pumped in from $10 \mathrm{~m}$ in depth) at a rate of $\sim 300 \mathrm{l} \mathrm{h}{ }^{1}$. Water temperature throughout our experiment was $7.2 \pm 0.3^{\circ} \mathrm{C}(\bar{X} \pm \mathrm{SE})$. The effects of scallop size, crevice size and light on the proportion of scallops found in refuges were analyzed using a 3-factor ANOVA (Kirk 1982). An angular transformation was applied to the data prior to the analysis so that assumptions of variance homogeneity (Hartley's $F_{\max }, \mathrm{p}>0.05$ ) and normality (Shapiro-Wilks, p > 0.05) were respected. A significant interaction between scallop size and crevice size (see 'Results') was further analyzed using simple main-effect tests (Kirk 1982) which specifically tested the effect of scallop size for each crevice size. The latter tests re-examined the partition of variance associated with scallop size and with the interaction between scallop size and crevice size.

Field evaluation of size-specific refuge availability. Using SCUBA, we determined the density and dimensions of Spisula polynyma shells in 38 quadrats of $0.25 \mathrm{~m}^{2}$ at 15 to $17 \mathrm{~m}$ depth. To evaluate the cover area of shells in the field, we determined the relationship between cover area and shell height of $S$. polynyma shells. Using computer-assisted image analysis, we determined the area and dimensions of individual shells ( $\mathrm{n}=12$ ) from images produced on a digital scanner. Then, we performed regression analysis on log transformed data to determine the relationship between cover area and shell height of individual $S$. polynyma shells:

Shell area $\left(\mathrm{cm}^{2}\right)=2.695(\text { Shell height })^{1.535}$

$$
\mathrm{r}^{2}=0.90, \quad F_{1,11}=93.32, \mathrm{p}<0.0001
$$
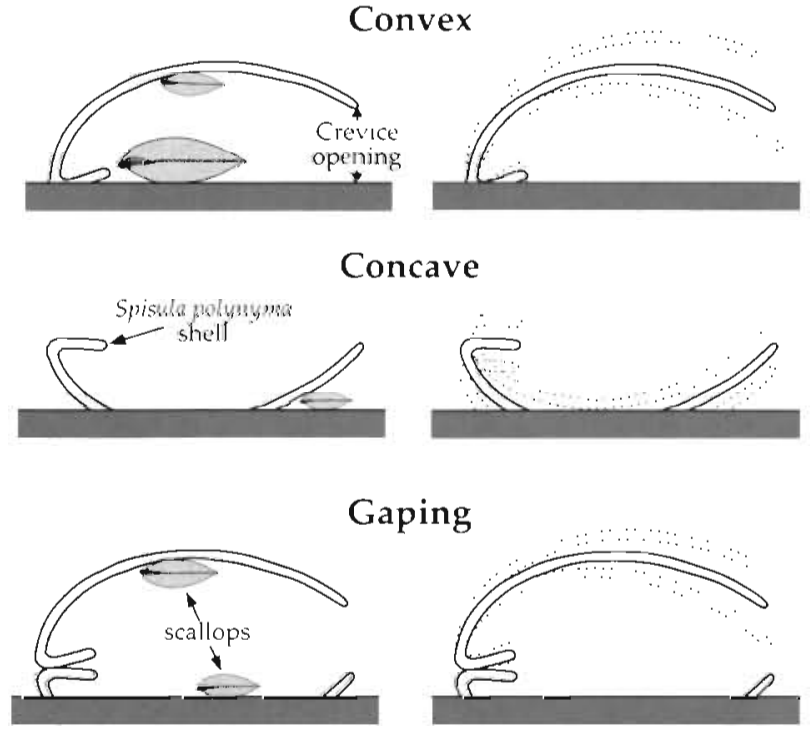

Fig. 2. Schematic representation (in cross-section) of different positions of shells of the bivalve Spisula polynyma used as refuges by Iceland scallops Chlamys islandica at Île du Fantôme, Mingan lslands. Typical variations in crevice size are represented by the dotted outlines on the right

Finally, using this relationship, we calculated the total cover area of shells in each of the 38 quadrats.

We additionally determined the position on the bottom (convex, concave or gaping; Fig. 2) and dimensions (shell height and length and size of the crevice opening) of 250 haphazardly sampled Spisula polynyma shells at 15 to $17 \mathrm{~m}$ depth to evaluate the proportion of refuges that were accessible to different-sized scallops. Scallops found in crevices under shells were collected to determine their shell height, length and width. Data on scallop density and size-specific frequency of refuge use were obtained from a previous field survey in which 875 scallops of various sizes were observed using SCUBA in 430 quadrats of $0.25 \mathrm{~m}^{2}$ in the same location and during the same period as in our present study (Arsenault \& Himmelman 1996b). We determined the proportion of $S$. polynyma shells which could be used as refuges for each of the 875 scallops, based on geometric criteria which considered both scallop size and refuge size (Appendix 1). The following criteria had to be respected for a scallop to have access to a refuge. Access to a refuge was assumed to be possible only if the scallop's shell width was smaller than or equal to the size of the crevice opening and if its shell height was smaller than or equal to the depth of the crevice. From these values, we calculated the mean frequency of adequately sized refuges for each of 5 size groups of scallops $(0-15,15-30,30-45,45-60$ and $>60 \mathrm{~mm}$ in shell height). The density of suitable refuges for each scallop size group was estimated by 
multiplying the total density of $S$. polynyma shells by the frequency of adequately sized refuges. We further calculated refuge occupancy, the proportion of adequately sized refuges which were occupied by scallops, for each size group

\section{RESULTS}

\section{Effect of crevice size on size-specific refuge use}

Our laboratory experiment indicated that the frequency of refuge use varied markedly with scallop size and crevice size (Table 1, Fig. 3). A significant interaction between the latter factors indicated that the effect of crevice size on refuge use varied among scallop sizes (Table 1, Fig. 3). Simple main-effect tests indicated that the frequency of refuge use varied among scallop sizes for refuges with openings of $15 \mathrm{~mm}$ $\left(F_{2,24}=64.19, \mathrm{p}<0.0001\right)$, there being a marked decrease in the use of these refuges as scallops increased in size (Fig. 3). This suggested that access to these crevices decreased as scallops increased in size. In contrast, the frequency of refuge use for refuges with $25 \mathrm{~mm}$ openings did not vary with scallop size $\left(F_{2,24}=\right.$

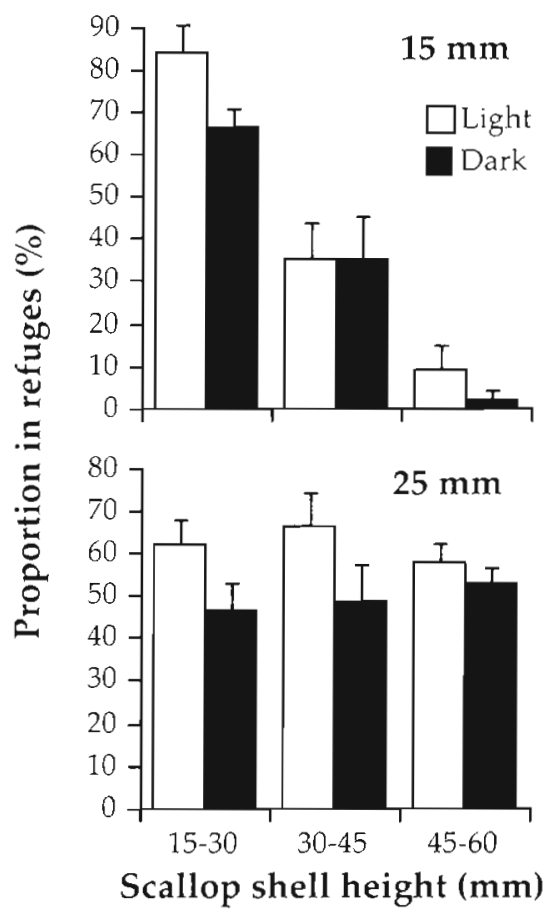

Fig. 3. Effects of crevice size, scallop size and light (presence or absence) on the frequency of refuge use by Iceland scallops Chlamys islandica in a laboratory experiment. Each treatment combination was replicated 3 times. Vertical bars are standard errors
Table 1 Chlamys islandica. Summary of a 3-factor ANOVA examining the effects of crevice size (15 and $25 \mathrm{~mm}$ ), scallop size $(15-30,30-45$ and $45-60 \mathrm{~mm}$ ) and light (presence or absence) on the frequency of refuge use by Iceland scallops in a laboratory experiment. Each factor combination was replcated 3 times and the data were angular transformed prior to analysis

\begin{tabular}{lrrrrr}
\hline Source of variation & df & $\begin{array}{c}\text { MS } \\
\left(\times 10^{-3}\right)\end{array}$ & $F$ & p \\
\hline Crevice size & 1 & 454.25 & 23.838 & $<0.001$ \\
Scallop size & 2 & 599.25 & 31.447 & $<0.001$ \\
Crevice size $\times$ scallop size & 2 & 625.82 & 32.842 & $<0.001$ \\
Light & 1 & 148.36 & 7.786 & 0.010 \\
Crevice size $\times$ light & 1 & 0.06 & 0.003 & 0.955 \\
Scallop size $\times$ light & 2 & 8.80 & 0.462 & 0.636 \\
Crevice size $\times$ & 2 & 18.80 & 0.987 & 0.387 \\
scallop size $\times$ light & & & & \\
Residual & 24 & 19.06 & & \\
\hline
\end{tabular}

$0.11, \mathrm{p}=0.90)$. These results suggested that the decrease in refuge use with size does not result from behavioural changes in the tendency to use refuges but rather because the required size of refuges increases with scallop size. This was further indicated by the relationship between crevice size and shell width for scallops found in refuges; $98.6 \%$ (283/287) of scallops occupying refuges had a width smaller than or equal to the size of the crevice opening. Finally, for all sizes of scallops, refuge use was slightly $(7.9 \%)$ higher in light than in darkness (Table 1, Fig. 3).

\section{Field evaluation of size-specific refuge availability}

At Île du Fantôme, Spisula polynyma shells were abundant $\left(\bar{X}=2.3\right.$ shells $\left.0.25 \mathrm{~m}^{-2}, \mathrm{SE}=1.1\right)$, similar in size $(83.3 \pm 0.5 \mathrm{~mm}$ in shell height and $116.6 \pm 0.6 \mathrm{~mm}$ in shell length) and covered $6.4 \pm 0.7 \%$ of the bottom $(\bar{X} \pm \mathrm{SE})$

The geometric criteria used to evaluate refuge accessibility provided realistic estimates of size-specific refuge availability, as $82 \%(59 / 72)$ of scallops found in crevices under Spisula polynyma shells respected these criteria. The proportion of sufficiently large crevices under $S$. polynyma shells decreased markedly with increasing scallop size (Fig. 4). Convex refuges were accessible to a broader range of scallop sizes and were more abundant (63\%) than either concave $(33 \%)$ or gaping refuges $(4 \%)$ (Fig. 4 ).

Size-related changes in the frequency of shell refuge use were strongly related to the availability of adequately sized shell refuges (Pearson's correlation, $\mathrm{r}=$ $0.984, p=0.003$; Table 2), which suggested that the 
Table 2. Summary of parameters describing the use of shells of Spisula polynyma as refuges by Iceland scallops at $\hat{l}$ le du Fantôme, in the Mingan lslands

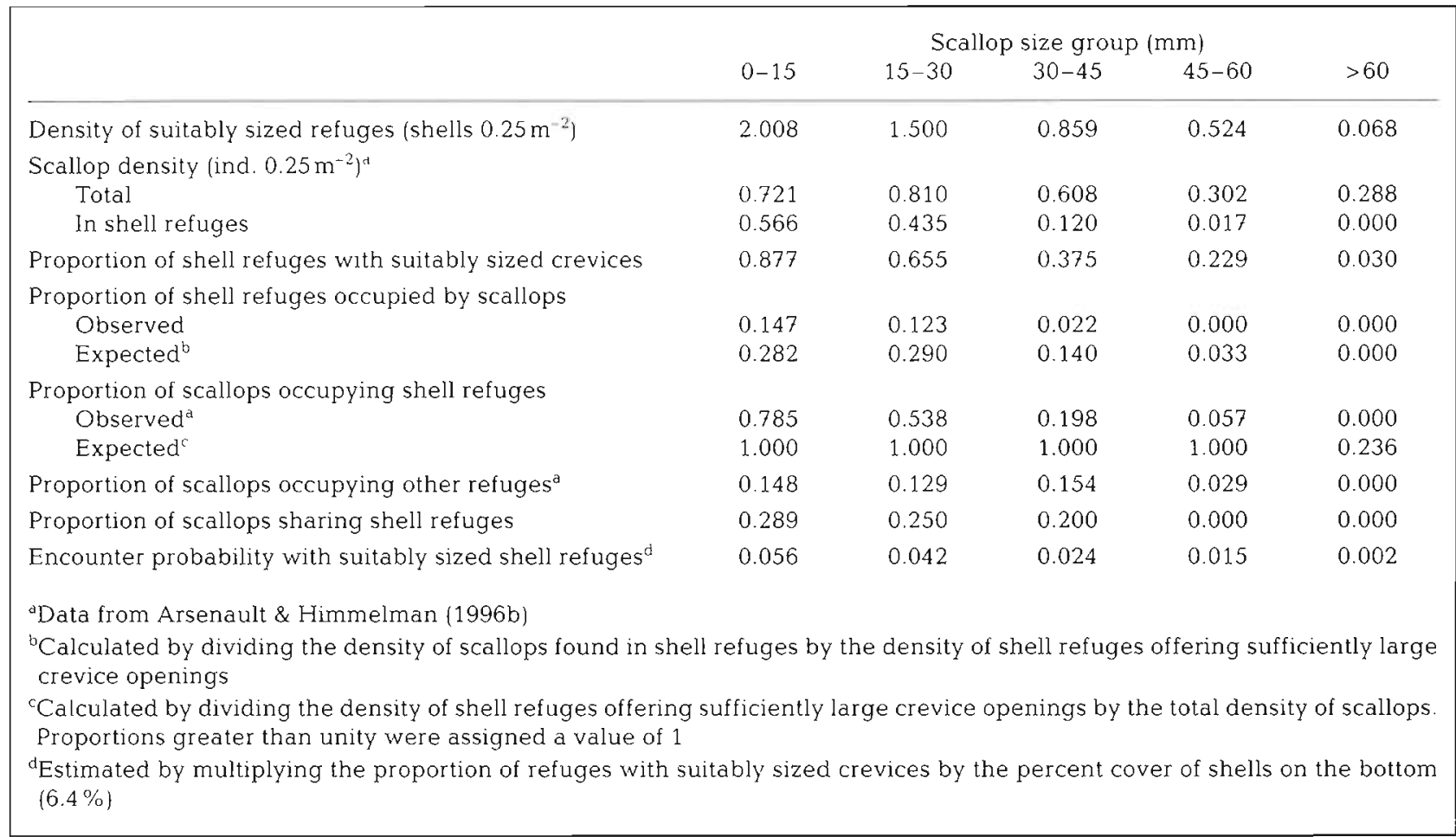

size structure of shell refuges determined size-specific refuge use. However, only a small proportion $(<15 \%)$ of adequately sized refuges were occupied by scallops,

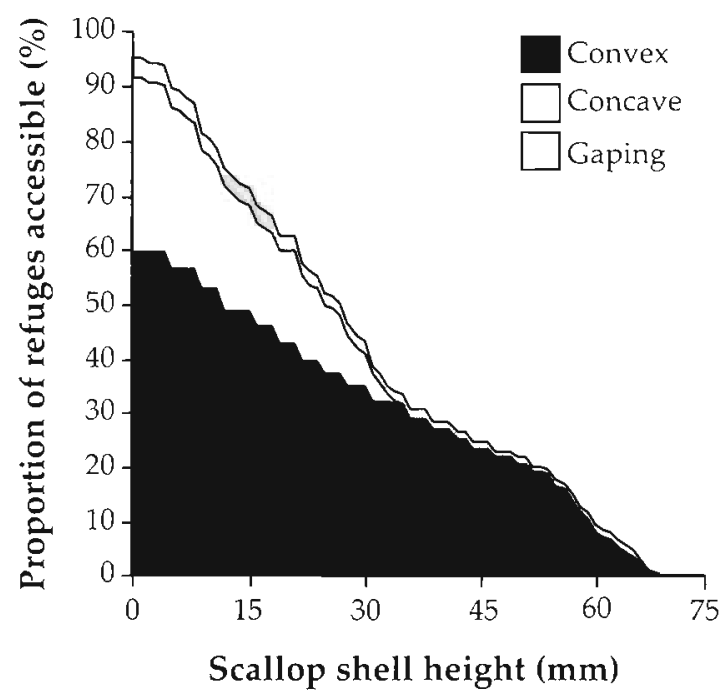

Fig. 4. Proportion of shells of the bivalve Spisula polynyma which provide crevices of suitable size for different-sized Iceland scallops Chlamys islandica at Île du Fantôme, Mingan Islands. Different textures indicate the 3 types of refuges as illustrated in Fig. 2 indicating that refuges at île du Fantôme were used below their carrying capacity (Table 2). Further, the proportion of refuges occupied by scallops decreased with increasing scallop size (Table 2). Of the 61 shell refuges occupied by scallops, $13 \%$ (8/61) sheltered more than 1 individual. The proportion of scallops sharing refuges decreased markedly with scallop size (Tables $2 \& 3$ ).

Table 3. Number of different-sized Iceland scallops Chlamys islandica sharing shell refuges as determined from sampling of 250 Spisula polynyma shells at 15 to $17 \mathrm{~m}$ depth at Île du Fantôme in the Mingan Islands. Only the 8 shells listed sheltered more than 1 scallop

\begin{tabular}{|cccc|}
\hline Spisula shell & \multicolumn{4}{c|}{ Scallop shell height (mm) } \\
& $0-15$ & $15-30$ & $30-45$ \\
\hline 1 & 1 & - & 1 \\
2 & 1 & 1 & - \\
3 & 1 & - & 1 \\
4 & 2 & - & - \\
5 & 2 & - & - \\
6 & 1 & 2 & - \\
7 & 1 & 2 & - \\
8 & 2 & 1 & 2 \\
Total & 11 & 6 & \\
\hline
\end{tabular}




\section{DISCUSSION}

Our laboratory experiment indicates that the frequency of refuge use by Iceland scallops does not vary with scallop size when entrances to refuges are sufficiently large. This suggests that the decrease in the scallops' use of refuges as they increase in size is not caused by behavioural changes in their tendency to use refuges. Rather, because the size of crevices used increases with scallop size, the size structure of refuges could determine size-specific refuge use. Our field measurements and geometric criteria indicate that the availability of suitably sized shell refuges decreases markedly with increasing scallop size. The strong positive correlation between the frequency of shell refuge use and the availability of shell refuges for differentsized scallops suggests that the shift from refuges to exposed surfaces is caused by decreasing availability of suitably sized refuges as scallops increase in size.

At Île du Fantôme, small Iceland scallops are mainly found in shallow water $(15 \mathrm{~m})$ likely because of the high density of larval settlement substrata such as filamentous red algae and hydroids (Arsenault \& Himmelman 1996a). Also, recruitment of scallops in shallow water may be enhanced by the abundant shell debris which provides juvenile scallops with refuges from predators (Arsenault \& Himmelman 1996b). Living Spisula polynyma are particularly abundant in shallow waters and the abundant $S$. polynyma shells are a result of predation by the seastar Leptasterias polaris or other sources of mortality. The size of crevices provided by the shell litter is likely determined by factors such as sediment erosion under and around shells, rates of degradation of shells and their hinge, and manipulation of shells by large benthic organisms such as crabs. The limited availability of refuges with large crevice openings is possibly explained by the tendency of shells to collapse on the bottom, or turn over, once the support from the underlying substrata is reduced beyond a certain point by sediment erosion.

Quantifying refuge availability is important in understanding the population dynamics of crevicedwelling animals because the availability of suitably sized refuges may cause density-dependent regulation of abundance and size structure (Caddy \& Stamatopoulos 1990). For example, the hermit crab is a shelter-dwelling animal which can outgrow its supply of refuges (gastropod shells) before it attains a less vulnerable size (Vance 1972a, b. Scully 1983). Consequently, limited availability of adequately sized refuges may produce a survival bottleneck. Similarly, the sizes of bioeroded holes on coral reefs may limit populations of crevice-dwelling crustaceans (Steger 1987, Moran \& Reaka 1988). The availability of crevices may also limit breeding densities of birds
(Brawn \& Balda 1988), cephalopods (Iribarne 1990) and crabs (Beck 1995), which brood in crevices

Although refuges are reported to potentially affect the population dynamics of many species, few studies have evaluated refuge availability in the field (Vance 1972a, b. Howard 1980, Steger 1987. Wahle \& Steneck 1.991). This may be due in part to the difficulty in quantifying refuge availability, especially for animals using a wide variety of refuge types. However, when a limited number of refuge types are utilized, as for Iceland scallops at Île de Fantôme, refuge availability can be evaluated by quantifying the density and size structure of refuges. For example, Steger (1987) used latex moldings of bioeroded holes in coral reefs to evaluate the availability of refuges for different-sized gonodactylid crustaceans. Our evaluation of refuge availability was limited to the refuges provided by shells of the bivalve Spisula polynyma, which accounted for $80 \%$ of the refuges used by Iceland scallops at Île du Fantóme (Arsenault \& Himmelman 1996a). Because $<60 \mathrm{~mm}$ scallops occasionally occupied other refuges, such as crevices under rocks, our estimates of refuge availability may have been slightly underestimated, especially for smaller scallops (Table 2). Nevertheless, our results show that the proportion of accessible shell refuges at Île du Fantôme decreases markedly with increasing scallop size. Our results are consistent with Caddy \& Stamatopoulos' (1990) view that, because of fractal expectations, the availability of suitably sized crevices in naturally dissected surfaces should generally decrease with increasing body size. Similar sizerelated decreases in refuge availability are reported for gonodactylid crustaceans (Steger 1987) and Patagonian octopus (Iribarne 1990).

The density of suitably sized shell refuges at Île du Fantome was generally greater than the density of Iceland scallops. However, the number of suitably sized refuges occupied by scallops was low $(<15 \%)$ and decreased with increasing scallop size. This indicates that refuges were utilized below their carrying capacity. In fact, refuge occupancy was lower than would be expected if all of the cryptic scallops had individually occupied refuges (Table 2). For example, the density of $<15 \mathrm{~mm}$ scallops occupying shell refuges was 0.566 ind. $0.25 \mathrm{~m}^{-2}$ and the density of shell refuges offering suitably sized crevices for this size group was 2.008 shells $0.25 \mathrm{~m}^{-2}$. Thus, we should expect $28.2 \%$ of available refuges to be occupied by $<15 \mathrm{~mm}$ scallops (density of scallops occupying shell refuges/density of suitably sized refuges). However, only $14.7 \%$ were occupied by $<15 \mathrm{~mm}$ scallops. The differences between observed and expected refuge occupancy were potentially because scallops occasionally shared refuges. That small scallops $(<15 \mathrm{~mm})$ shared refuges more frequently than larger individuals could explain 
why the difference between observed and expected values decreased with scallop size (Table 2). That $18 \%$ $(13 / 72)$ of scallops found in refuges occupied refuges of unsuitable size may also have decreased the observed refuge occupancy since the latter measurement only considered refuges of suitable size. In all cases when unsuitable refuges were occupied, the size of the crevice openings was markedly smaller than that required for the scallops to enter these refuges. These scallops possibly became trapped in the refuges because the shells had collapsed on the bottom due to sediment erosion or they could have entered these refuges at a smaller size and outgrown the size of the refuge openings.

Given that the density of suitably sized refuges at Île du Fantôme was generally greater than the density of scallops, the proportion of scallops occupying refuges should have been greater than observed (Table 2). In fact, the availability of shell refuges was such that all $<60 \mathrm{~mm}$ scallops could have occupied refuges. However, the proportion of scallops in shell refuges was lower than expected and decreased markedly with increasing scallop size (Table 2). Andrewartha \& Birch (1954) emphasize that resource availability depends not only on the numerical abundance of a resource but also on the probability of its being found. They suggest that even though only a small proportion of a resource may be used, it can be in short supply if it is distributed in such a way that its accessibility is reduced, such as when a resource is contagiously distributed. Although not considered by Andrewartha \& Birch, the size of a resource may also affect its accessibility by reducing the probability of its being found. Thus, even though the shells used as refuges by scallops at Île du Fantome are numerically abundant, their low percent cover $(6.4 \%)$ may decrease the probability of their being found and, hence, could explain the lower than expected use of refuges. Scallops swim by repeatedly opening and closing their valves which forces a jet of water from the mantle cavity (Brand 1991). In a typical swimming bout, a scallop leaves the seabed at an angle of 30 to $50^{\circ}$, then the trajectory levels off so that it swims horizontally, and finally it passively sinks to the seabed (Brand 1991, Arsenault pers. obs.). Encounter rates with shell refuges depend on the probability that scallops encounter suitable refuges at the end of swimming bouts (encounter probability) and the time required to locate a suitable refuge (search time). Encounter probability is likely determined by the size of shell refuges (cover area) and by the size of the scallop's perceptual field. However, the probability that the opening to an encountered shell crevice is sufficiently large depends on the proportion of refuges available to each scallop size. Thus, encounter probability can be roughly estimated by multiplying the probability of encountering a shell refuge by the probability that the encountered refuge is sufficiently large. For example, in spite of the high density of adequately large shell refuges for $30-45 \mathrm{~mm}$ scallops (0.859 shells $0.25 \mathrm{~m}^{-2}$ ), the probability that this sized scallop encounters an adequately large refuge after a single swimming bout is relatively low (Table 2). The probability of a 30-45 $\mathrm{mm}$ scallop encountering a shell refuge at the end of a swimming bout is 0.064 (based on the proportion of the bottom covered by shells) and the probability that the encountered refuge is sufficiently large is 0.375 . Thus, the probability that this sized scallop encounters a refuge of suitable size after a swimming bout is $0.024(0.064 \times 0.375)$. Encounter probabilities calculated in this way are likely underestimated because they do not consider the scallop's perceptual field which may increase its probability of locating a shell refuge.

The rate at which scallops encounter suitably sized refuges also depends on search time. The above calculations assume that search time does not vary with scallop size. We do not have data on the swimming frequency of different-sized scallops. However, Vahl \& Clausen (1980) examined the swimming frequency of Iceland scallops in Norway by removing all individuals from fixed areas and then counting the number of scallops migrating into these areas at varying time intervals. They found that different sizes of scallops swim at about the same frequency (only every $31 \mathrm{~d}$ ). At this swimming frequency, scallops at Île du Fantôme would encounter suitable refuges at rates of $0.0018,0.0014$, $0.0008,0.0005,0.00006$ refuges $\mathrm{d}^{-1}$ for $0-15,15-30$, $30-45,45-60$ and $>60 \mathrm{~mm}$ scallops, respectively (encounter probability/31 d). This would mean that the above scallop sizes should encounter suitably sized refuges in approximately $18,24,42,68$ and 521 swimming bouts or 558, 744, 1302, 2108 and $16151 \mathrm{~d}$, respectively. Iceland scallops likely swim more frequently than reported by Vahl \& Clausen (1980); nevertheless, it is clear that the number of swimming bouts required to encounter suitably sized refuges increases markedly with increasing scallop size. This suggests that scallops should have increasing difficulty in locating suitably sized refuges as they increase in size. That the frequency of shell refuge use is strongly correlated with encounter probability (Pearson's correlation, $\mathrm{r}=$ $0.983, p=0.003$ ) suggests that size-related changes in encounter rates with refuges may be involved in determining the size-related decrease in the scallop's use of refuges (Table 2). Low encounter rates could also explain why only a small proportion of available refuges are occupied by scallops.

If refuges are difficult to locate, this could increase the time scallops are exposed to predators while searching for refuges. This is likely critical for small 
scallops ( $<30 \mathrm{~mm}$ in shell height) because their survival is markedly lower when outside of refuges (Arsenault \& Himmelman 1996b). As a result, encounter rates with suitably sized refuges could produce a demographic bottleneck limiting the abundance of recruiting scallops. Further studies are needed to evaluate this hypothesis.

Knowledge of factors which limit abundance and size structure is important in understanding and managing populations of commercially exploited species (Caddy \& Stamatopoulos 1990). Several studies of crevicedwelling animals have shown that experimentally increasing the abundance of refuges can increase recruitment success (Steger 1987, Eggleston et al. 1990, Dumbauld et al. 1993, Beck 1995). For example, Dumbauld et al. (1993) showed that the addition of oyster shells in intertidal recruitment habitats increases the abundance of young-of-the-year Dungeness crabs Cancer magister by enhancing survival. Our results suggest that encounter rates with suitable refuges potentially regulate the abundance of juvenile Iceland scallops. Scallop fishermen in the Mingan Islands generally shuck scallops and discard shells while making their way back to port and at dockside. Our results and those of Arsenault \& Himmelman (1996a, b) suggest that survival of recruits in natural habitats would likely be enhanced by distributing shells along the bottom within scallop beds or in coastal nursery areas. Further, these findings may be useful for bottom culture of scallops because they suggest that survival of seeded juvenile scallops would be enhanced by increasing shell litter or other types of refuges in seeded areas.

Appendix 1. Geometric criteria used in determining size-specific refuge suitability

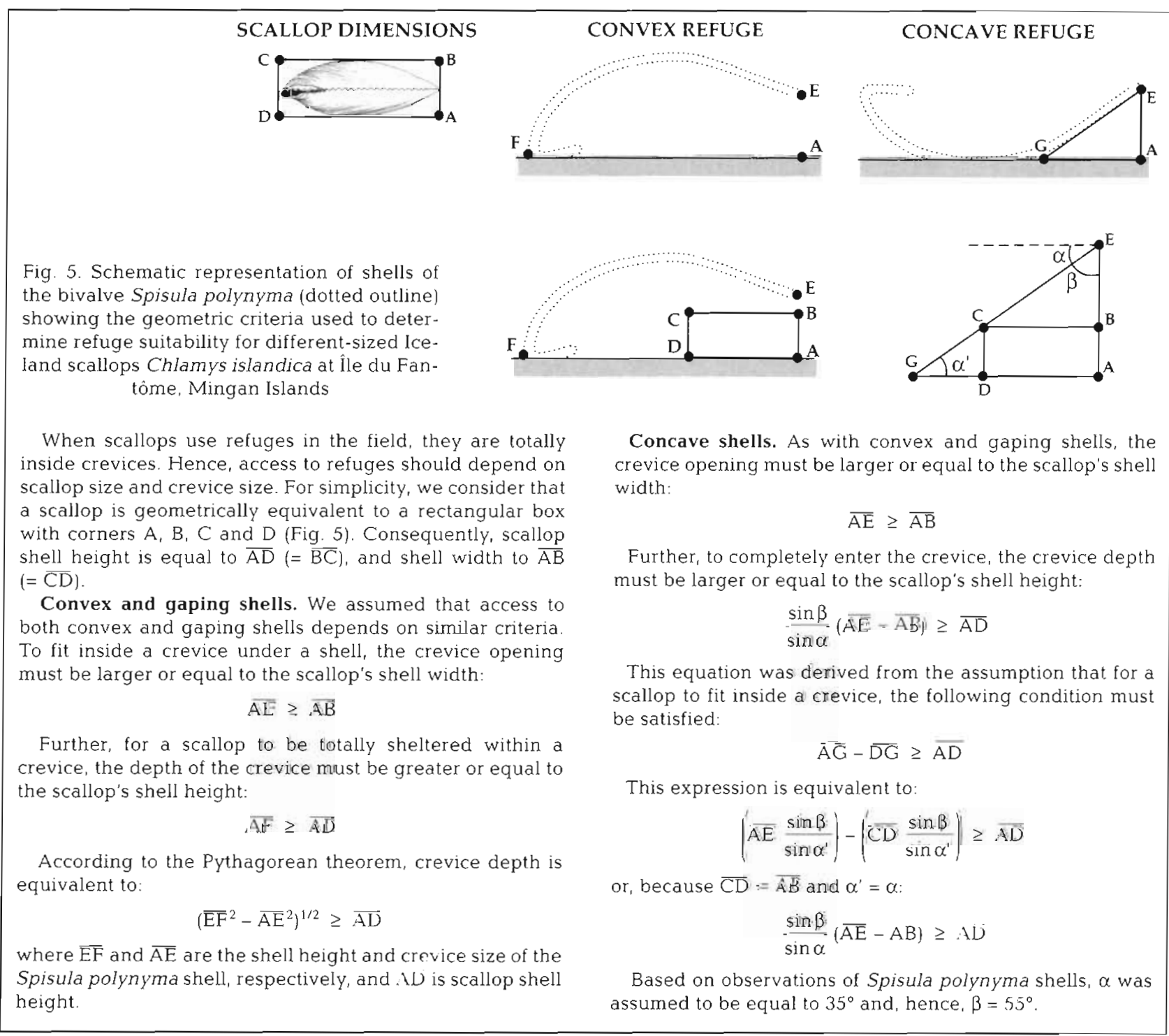


Acknowledgements. We are grateful to S. Blanchet and $\mathrm{M}$. Vaugeois for their aid during field work and to R. E. Scheibling, J. Bovet, J. N. McNeil and R. Rochette for insightful comments and discussions. This study was funded by NSERC operation grants to J.H.H. D.J.A. received financial support from NSERC and FCAR postgraduate scholarships.

\section{LITERATURE CITED}

Andrewartha HG, Birch LC (1954) The distribution and abundance of animals. University of Chicago Press, Chicago

Arsenault DJ, Girard P. Himmelman JH (1997) Field evaluation of the effects of refuge use and current velocity on the growth of juvenile Iceland scallops, Chlamys islandica (O. F, Müller, 1776). J Exp Mar Biol Ecol 217:31-45

Arsenault DJ, Himmelman JH (1996a) Ontogenetic habitat shifts of the Iceland scallop, Chlamys islandica (Müller, 1776), in the northern Gulf of St. Lawrence. Can J Fish Aquat Sci 53:884-895

Arsenault DJ, Himmelman JH (1996b) Size-related changes in vulnerability to predators and spatial refuge use by juvenile Iceland scallops (Chlamys islandica). Mar Ecol Prog Ser 140:115-122

Beck MW (1995) Size-specific shelter limitation in stone crabs: a test of the demographic bottleneck hypothesis. Ecology 76:968-980

Brand AR (1991) Scallop ecology: distributions and behaviour In: Shumway SE (ed) Scallops: biology, ecology and aquaculture. Elsevier, New York, p 517-584

Brawn JD, Balda RP (1988) Population biology of cavity nesters in northern Arizona: do nest sites limit breeding densities? Condor 90:61-71

Caddy JF, Stamatopoulos C (1990) Mapping growth and mortality rates of crevice-dwelling organisms onto a perforated surface: the relevance of 'cover' to the carrying capacity of natural and artificial habitats. Estuar Coast Shelf Sci 31:87-106

Caldwell JP, Thorp JH, Jervey TO (1980) Predator-prey relationships among larval dragonflies, salamanders, and frogs. Oecologia 46:285-289

Dumbauld BR, Armstrong DA, McDonald TL (1993) Use of oyster shell to enhance intertidal habitat and mitigate loss of Dungeness crab (Cancer magister) caused by dredging. Can J Fish Aquat Sci 50:381-390

Eggleston DB, Lipcius RN, Miller DL, Coba-Cetina L (1990) Shelter regulates survival of juvenile Caribbean spiny lobster Panulirus argus. Mar Ecol Prog Ser 62:79-88

Ekman S (1953) Zoogeography of the sea. Sidwick and Jackson, London

Giguère $M$, Miller $M$ (1993) Review of scallop fisheries in Quebec. Can Ind Rep Fish Aquat Sci 217:1-27

Gilkinson KD, Gagnon JM (1991) Substratum associations of natural populations of Iceland scallops, Chlamys islandica Müller 1776, on the northeastern Grand Bank of Newfoundland. Am Malacol Bull 9:59-67

Heck KLJ, Wilson KA (1987) Predation rates on decapod crustaceans in latitudinally separated seagrass communities: a study of spatial and temporal variation using tethering techniques. J Exp Mar Biol Ecol 107:87-100

Howard AE (1980) Substrate controls on the size composition of lobster (Homarus gammarus) populations. J Cons Int Explor Mer 39:130-133

Iribarne 00 (1990) Use of shelter by small Patagonian octopus Octopus tehuelchus: availability, selection and effects on fecundity. Mar Ecol Prog Ser 66:251-258

Kauffman EG (1969) Form, function and evolution. In: Moore
RC (ed) Treatise on invertebrate paleontology. The Geological Society of America and the University of Kansas, New York, p N130-N205

Kirk RE (1982) Experimental design: procedures for the behavioral sciences. Brooks/Cole, Belmont

L'Abbé-Lund JH, Langeland A, Jonsson B, Ugedal O (1993) Spatial segregation by age and size in Arctic charr a trade-off between feeding possibility and risk of predation. J Anim Ecol 62:160-168

Main KL (1987) Predator avoidance in seagrass meadows: prey behavior, microhabitat selection, and cryptic coloration. Ecology 68:170-180

Moran DP, Reaka ML (1988) Bioerosion and availability of shelters for benthic reef organisms. Mar Ecol Prog Ser $44: 249-263$

Olson MH (1996) Ontogenetic niche shifts in largemouth bass: variability and consequences for first-year growth. Ecology 77:179-190

Pohle DG, Bricelj VM, Garcia-Esquivel Z (1991) The eelgrass canopy: an above-bottom refuge from benthic predators for juvenile bay scallops Argopecten irradians. Mar Ecol Prog Ser 74:47-59

Rowe L, Ludwig D (1991) Size and timing of metamorphosis in complex life cycles: time constraints and variation. Ecology $72: 413-427$

Scully EP (1983) The behavioral ecology of competition and resource utilization among hermit-crabs. In: Rebach S, Dunham DW (eds) Studies in adaptation: the behavior of higher Crustacea. John Wiley and Sons, New York, p 23-56

Seed R, Brown RA (1978) Growth as a strategy for survival in two marine bivalves, Cerastoderma edule and Modiolus modiolus. J Anim Ecol 47:283-292

Semlitsch RD, Gibbons JW (1988) Fish predation in size-structured populations of treefrog tadpoles. Oecologia 75: 321-326

Sih A (1987) Predators and prey lifestyles: an evolutionary overview. In: Kerfoot WC, Sih A (eds) Predation: direct and indirect impacts on aquatic communities. University Press of New England, Hanover, p 203-224

Steger R (1987) Effects of refuges and recruitment on gonodactylid stomatopods, a guild of mobile prey. Ecology 68 : $1520-1533$

Stein RA, Magnuson JJ (1976) Behavioral response of crayfish to a fish predator. Ecology 57: 751-761

Vahl O, Clausen B (1980) Frequency of swimming and energy cost of byssus production in Chlamys islandica (O.F. Müller). J Cons Int Explor Mer 38:101-103

Vance RR (1972a) Competition and mechanisms of coexistence in three sympatric species of intertidal hermit crabs. Ecology 53:1062-1072

Vance RR (1972b) The role of shell adequacy in behavioral interactions involving hermit crabs. Ecology 53:1075-1083

Wahle RA, Steneck RS (1991) Recruitment habitats and nursery grounds of the American lobster Homarus americanus: a demographic bottleneck? Mar Ecol Prog Ser 69:231-243

Wahle RA, Steneck RS (1992) Habitat restrictions in early benthic life: experiments on habitat selection and in situ predation with the American lobster. J Exp Mar Biol Ecol $157: 91-114$

Werner EE (1988) Size, scaling, and the evolution of complex life-cycles. In: Ebenmen B. Persson L (eds) Size-structured populations. Springer-Verlag, Berlin, p 60-81

Werner EE, Hall DJ (1988) Ontogenetic habitat shifts in bluegill: the foraging rate-predation risk trade-off. Ecology 69:1352-1366

Wiborg KF (1963) Some observations on the Iceland scallop Chlamys islandica (Müller) in Norwegian waters. FiskDir Skr Ser Havunders 13:38-53 